(i-COME'20)

INTERNATIONAL CONFERENCE ON COMMUNICATION AND MEDIA 2020

\title{
THE INFLUENCE OF CSR ON COMPANY'S NON-FINANCIAL PERFORMANCE: A REVIEW ON LITERATURE
}

\author{
Wan Nor Hidayah Wan Afandi (a)* \\ *Corresponding author
}

(a) Kolej Universiti PolyTech MARA,Kuala Lumpur, Malaysia, wandaafandi@gmail.com

\begin{abstract}
Corporate ethical behaviours has become one of the main factors that influence an organisation's sustainability. Ethical and responsible behaviours help companies to foster a positive reaction among society including its employees to ensure their perpetual support. Companies have to pay considerable attention to their employees to understand employees' expectations toward them. The relation between corporate social responsibility (CSR) and company's performance has induced much interest among researchers which usually roams around financial performance or company's profitability. The purpose of this article is to review existing literature of the relationship between CSR and non-financial performance. The indicator of a company's non-financial performance in this article will be based on employee commitment toward the CSR's initiative by the company. In exploring the relationship between CSR and employee's commitment, this paper draws upon the mediating role of organisational justice. It suggests that employees develop general justice perceptions towards companies based on the level of fairness that company exhibits.
\end{abstract}

2357-1330 @ 2021 Published by European Publisher.

Keywords: Corporate social responsibility, employees' commitment, non-financial performance, organisational justice 


\section{Introduction}

From the perspective of profitable organisations, improving performance is crucial for positioning purpose and to stay relevant (Burg-Brown, 2016). Organisations must evaluate its performance to better understand what they can do or rectify to improve their ability to perform (Yaghoobi \& Haddadi, 2016). Countless efforts have been done by researchers to explore on how to enhance, shape and sustain organisational performance since it is related to organisations' profitability and survival (Singh et al., 2016).

Prior studies found that corporate social responsibility (CSR) is significantly correlated with an organisation's performance; financial and non-financial (Choongo, 2017; Kim et al., 2016). CSR becomes a commitment to organisations that improves the quality of life of the society (Khatun et al., 2015) and solutions to social issues. Thus, CSR is believed to become one of the vital elements of modern business since they are expected to do more than what is required by law (Caroll, 2015). Furthermore, companies are becoming more aware of the impact of their behaviours on stakeholders (Newman et al., 2015).

Employees is one of the most important stakeholders which gives impact and at the same time can be affected by a company's activities (Azim, 2016). Their commitment towards companies have a significant influence on organisation's performance (Andrew, 2017). In recent years, it is evident that CSR studies began to focus on employees' outcomes. Those studies explore the relationship between CSR and employees' commitment (Low \& Ong, 2015b; Low et al., 2017), organizational citizenship behavior (Azim, 2016), job satisfaction (Low \& Ong, 2015a), employees' turnover (Kim et al., 2016; Low et al., 2017), job performance (Newman et al., 2015) and employee engagement (Azim, 2016; Flammer \& Luo, 2017).

This conceptual paper, however, is meant to collect relevant literature and infer to theoretical framework that explains CSR - employees' commitment relationship through organisational justice. Mixed findings in prior studies has been concluded to may have caused by the absence of mediating factor. In this paper, non-financial performance refers to employees' commitment. It also explains about the 3 dimensions of organisational justice as mediator; procedural, distributive and interactional.

The article is organized as follows: a framework of literature review, a theoretical framework and the research hypotheses and a brief explanation on potential theoretical contribution.

\section{Literature Review}

\subsection{Corporate Social Responsibility (CSR)}

Despite the increase number of CSR studies, there is still no uniform definition or concept of CSR. CSR and its concept have been under discussion since the Standard Oil Company executed its philanthropy program by providing financial aid to a university in 1953 (Malik et al., 2015). The highest legislative body in the EU, European Commission (2011) recommended that CSR can be defined as companies' good gestures that goes above and beyond legal obligations which contributes to the betterment of society as well as environment. 
However, based on CSR literatures, most CSR definitions which are initiated by scholars are rooted from Caroll (2015) suggesting CSR pyramid (Low, 2016). Caroll's most popular CSR model postulated four-dimensions of CSR; 1) economic - obligations to an organisation to generate profits, 2) legal - obligations to adhere to regulations and laws, 3) ethical - obligations to display ethical manner and 4) discretionary - to go above and beyond stakeholders' expectations. Kim et al. (2016) conceptually evaluated these four CSR dimensions in their study on the impact of CSR and internal marketing on organisational commitment and turnover intention. Their study confirms that CSR in the casino industry is composed of that Caroll (2015) CSR dimension.

However, Irma and Lau (2016) proposed five dimensions of CSR as they assessed the CSR performance of public-listed companies in Malaysia and they are; economic prosperity, marketplace, community, workplace and environment. This is quite similar to what was proposed by Zahari et al. (2020) who investigated the implementation of CSR at Malaysian property developers. It was adopted from CSR framework initiated by Bursa Malaysia in 2006 which comprises of environment, marketplace, workplace and community. CSR is a multi-disciplinary concept and thus the construct of CSR will be different according to the context of which it is studied (Low, 2016).

\subsection{Non-financial Performance}

In measuring the organisational performance, it can be expressed based on two approaches; approach and subjective (Al-Samman \& Al-Nashmi, 2016). The objective approach relates to financial while subjective is from the perceptual aspects or non-financial. The non-financial performance revolves around attaining sustainability and incorporates factors which help the organizations in enhancing its financial result (Alrowwad et al., 2017).

Earlier studies on corporate social responsibility also measures a company's non-financial performance such as employees' commitment (Azim, 2016; Choongo, 2017), organisational citizenship behavior (Azim, 2016; Luu, 2017), employees' turnover (Chaudhary, 2017; Lin \& Liu, 2017), job performance (Shin et al., 2016) and employee engagement (Azim, 2016; Flammer \& Luo, 2017; Obeidat, 2016). This paper discussed about employees' commitment as one of the measures of non-financial performance.

According to O'Reilly and Chatman (1986) as cited by Low and Ong (2015b), psychological attachment to the organisation explains employees' commitment. It refers to the extent in which employees feel devoted to the organisations they work for (Irefin \& Mechanic, 2014) or the extent of employees' loyalty (Choongo, 2017). In striving for organisational success and survival, employees' commitment seems to play a big role. Allen and Meyer (1990) conceptualised employees' commitment into three components; affective (desire), continuance (cost) and normative (obligation). Affective refers to emotional attachment, identification and involvement of employees in the company. Continuance stems from assessment of respective cost and benefit while normative is the feeling of obligation to stay.

A considerate amount of literature has been published on employees' commitment and its impact on organisational outcomes. Andrew (2017) found a fairly high relationship between employees' commitment and organisational performance. Individuals who were highly committed to their jobs are more productive and have a higher satisfaction level. 


\subsection{CSR on Employees' Commitment}

Ellemers et al. (2011) found that perceived CSR activities influence perceived morality of the organisation which indirectly impacts employees' job attitudes (commitment). Nevertheless, there are also studies that discover direct positive link between CSR employees' commitment (Kim et al., 2016). This is aligned with a study conducted by Zafar and Ali (2016) which discovered CSR actions as having positive influence on employees' commitment. They suggested social activities such as working for better environment, producing quality products and complying with government rules and regulations can help organisations to enhance employees' commitment.

In addition, employees are not only concerned about the pay check but they like to be associated with a socially-responsible organisation since it heightens their self-image and in turn, they reciprocate through positive attitudes and behaviours (Azim, 2016). However, in a longitudinal analysis by Choongo (2017), the association between CSR and employees' commitment is only partially accepted. It was suggested that future study deals with the drives that changes CSR-employees' commitment over time.

Based on a study on academia's attitude and behaviour, it is evident that CSR directly and indirectly influenced employees' commitment (Ahmad et al., 2020). The presence of organisational trust as mediator explains the indirect relationship between CSR and employees' commitment. The relationship between perceived CSR and employees' affective commitment is found to be mediated by ethics and moral (Bouraoui et al., 2019). While much of the scholarly work on CSR and its influence on employees' outcomes is conflicting, they also agree that CSR relates to the impact on stakeholders including employees.

\subsection{Organisational Justice as Mediating Factor}

Organisational justice refers to employees' perception on organisation's equal treatment towards them. Greenberg and Colquitt (2005) as quoted by Ha and Ha (2015) assert that perception of fairness is one significant antecedent affecting employees' attitudes and behaviours.

There are three key components of organisational justice, namely; 1) distributive justice refers to fairness in decisions made at workplace and equality in rewards distribution from the job outcome 2) procedural justice relates to decision making process fairness as perceived by employees and lastly 3 ) interactional justice discussed about relationship between employees and organisation.

Rauf (2015) found that distributive, procedural and interactional justice are all directly and positively correlated with organisational citizenship behaviour (OCB) of Sri Lankan employees. When employees believe that they receive equal treatment by employers, they are more likely to exhibit expected behaviours significantly.

Based on previous empirical studies of CSR - employees' outcomes, scholars are suggested to test mediating effect on the relationship (Farid et al., 2019). Organisational justice has been widely used in earlier research as mediator that explain how CSR can influence employees' attitude.

A research conducted by Sarfraz et al. (2018) found organisational justice partially mediates the relationship of perceived CSR - employees' outcomes. However, Farid et al. (2019) identified procedural and distributive as important underlying mechanism in explaining indirect relationship of perceived CSR 
and employees' outcomes; organisational citizenship behaviour (OCB) and work engagement. Their findings are supported by a study by Jung and Ali (2017) on employees in South Korea who found the relationship among internal CSR, organisational commitment and job satisfaction are fully mediated by both distributive as well as procedural justice.

Hence, based on existing literature of CSR, employees' commitment and organisational justice, this paper proposed the following theoretical model (Figure 01) to explain the relationship among variables.

H1 - There is a relationship between CSR and employees' commitment.

H2 - Organisational justice mediates the relationship between CSR and employees' commitment.

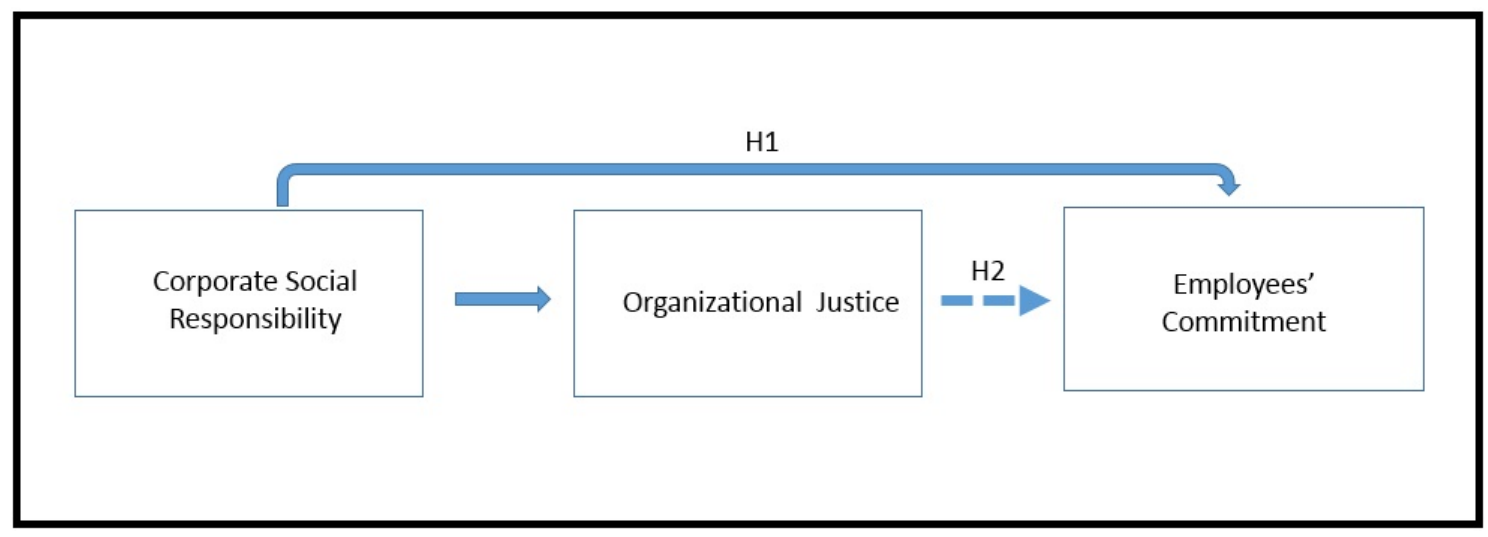

Figure 1. Proposed Theoretical Model

\section{Potential Theoretical Contribution}

It will expand the literature by suggesting which dimension of CSR will greatly impact which component of employees' commitment. It will also conform the role of organisational justice as mediator by assessing CSR as the predictors of the employees' commitment towards companies. Besides that, there will be a clear explanation on which component of organisational justice will highly mediate CSR employees' commitment relationship. This contribution will help managers to strategize their CSR programs to enhance employees' commitment at its best.

\section{Conclusion}

This article has presented mainly about the effect of CSR on the commitment among employees and the role of organisational justice as mediating factor. Different findings in CSR studies and its association with employees' outcomes have led to a conclusion that it could be due to; context of country of study, industry, ways of measuring CSR, methodological approaches or the period it was conducted and analysed. The mixed findings from empirical studies can also be the result of not considering mediating variables.

Despite mixed results obtained by previous researchers, CSR, if taken seriously by organisations, may influence the way employees see and feel about their organisations. Collectively, employees may break or make a company. 


\section{References}

Ahmad, R., Ahmad, S., Islam, T., \& Kaleem, A. (2020). The nexus of corporate social responsibility (CSR), affective commitment and organizational citizenship behaviour in academia: A model of trust. Employee Relations, 42(1), 232-247. https://doi.org/10.1108/ER-04-2018-0105

Alrowwad, A., Obeidat, B. Y., Tarhini, A., \& Aqqad, N. (2017). The impact of transformational leadership on organizational performance via the mediating role of corporate social responsibility: A structural equation modeling approach. International Business Research, 10(1), 199-221. http://dx.doi.org/10.5539/ibr.v10n1p199

Allen, N. J., \& Meyer, J. P. (1990). The measurement and antecedents of affective, continuance and normative commitment to the organization. Journal of Occupational Psychology, 63, 1-8. https://doi.org/10.1111/j.2044-8325.1990.tb00506.x

Al-Samman, E., \& Al-Nashmi, M. (2016). Effect of corporate social responsibility on non-financial organizational performance: Evidence from Yemani for-profit public and private enterprises. Social Responsibility Journal, 12(2), 247-262. https://doi.org/10.1108/SRJ-04-2015-0049

Andrew, A. (2017). Employees' commitment and its impact on organizational performance. Asian Journal of Economics, Business and Accounting, 5(2), 1-13. https://doi.org/10.9734/AJEBA/2017/38396

Azim, M. T. (2016). Corporate social responsibility and employee behavior: Mediating role of organizational commitment. Review of Business Management, 18(60), 207-225. http://doi.10.7819/rbgn.v18i60.2319

Bouraoui, K., Bensemmane, S., Ohana, M., \& Russo, M. (2019). Corporate Social Responsibility and Employees' Affective Commitment: A Multiple Mediation Model. Management Decision, 57(1), 152-167. https://doi.10.1108/MD-10-2017-1015

Burg-Brown, S. A. (2016). The relationship between leadership styles and organizational performance moderated by employee job satisfaction in United Government agencies (Publication No. 10240572) [Doctoral Dissertation, Capella University]. ProQuest Dissertation Publishing.

Caroll, A. B. (2015). Corporate social responsibility: the centerpiece of competing and complementary frameworks. Organizational Dynamics, 44, 87-96. http://dx.doi.org/10.1016/j.orgdyn.2015.02.002

Chaudhary, R. (2017). CSR and turnover intentions: Examining the underlying psychological mechanism. Social Responsibility Journal, 13(3), 643-660. https://doi.org/10.1108/SRJ-10-2016-0184

Choongo, P. (2017). A longitudinal study of the impact of corporate social responsibility on firm performance in SMEs in Zambia. Sustainability Journal, 9, 1-19. http://doi.10.3390/su9081300

Ellemers, N., Kingma, L., Burgt, J. V. E., \& Barreto, M. (2011). Corporate social responsibility as a source of organizational morality, employee commitment and satisfaction. Journal of Organizational Moral Psychology, 1(12), 97-124.

European commission. (2011). A renewed EU strategy 2011-14 for corporate social responsibility. Communication from the commission to the European Parliament, the council, the European economic and social committee and the committee of the regions. Brussels: European commission. http://eur-lex.europa.eu/LexUriServ/LexUriServ.do?uri=COM:2011:0681:FIN:EN:PDF

Farid, T., Ma, J., Castro-Gonzalez, S., Khattak, A., \& Khan, M. K. (2019). Employees' Perceptions of CSR, Work Engagement, and Organizational Citizenship Behavior: The Mediating Effects of Organizational Justice. International Journal Environmental Research Public Health, 16, 1731. https://doi.10.3390/ijerph16101731

Flammer, C., \& Luo, J. (2017). Corporate social responsibility as an employee governance tool: Evidence from a Quasi-experiment. Strategic Management Journal, 38, 163-183. http://doi.10.1002/smj.2492

Greenberg, J., \& Colquitt, J. A. (2005). Handbook of organizational justice. Lawrence Erlbaum Associates. 
Ha, J.-P., \& Ha, J. (2015). Organizational justice - affective commitment relationship in a team sport setting: The moderating effect of group cohesion. Journal of Management \& Organization, 21(1), 107-124. https://doi:10.1017/jmo.2014.67

Irefin, P., \& Mechanic, M. A. (2014). Effect of employee commitment on organizational performance in coca-cola nigeria limited Maiduguri, Borno State. IOSR Journal of Humanities and Social Science, 19, 3-41. https://www.iosrjournals.org

Irma, Y. M. Y., \& Lau, S. Y. (2016). Corporate Social Responsibility: Ranking Public Listed Companies in Malaysia. Reitaku Journal of Interdisciplinary, 24.

Jung, H.-J., \& Ali, M. (2017). Corporate Social Responsibility, Organizational Justice and Positive Employee Attitudes: In the Context of Korean Employment Relations. Sustainability, 9, 1992. https://doi.10.3390/su9111992

Khatun, K. M., Islam, M. A., Noor, I. M., \& Sa'aban, S. (2015). A review on trends of corporate social responsibility. The Social Sciences, 10(2).

Kim, J., Song, H. J., \& Lee, C.-K. (2016). Effects of corporate social responsibility and internal marketing on organizational commitment and turnover intentions. International Journal of Hospitality Management, 25-32. http://dx.doi.org/10.1016/j.ijhm.2016.02.007

Lin, C., \& Liu, M. (2017). Examining the effects of corporate social responsibility and ethical leadership on turnover intention. Personnel review, 46(3), 526-550. https://doi.org/10.1108/PR-11-20150293

Low, M. P. (2016). Corporate social responsibility and the evolution of internal corporate social responsibility in $21^{\text {st }}$ century. Asian Journal of Social Sciences and Management Studies, 3, 5674. http://www.asianonlinejournals.com/index.php/AJSSMS

Low, M. P., \& Ong, S. F. (2015a). The manifestation of internal corporate social responsibility on employees' behavior in small medium sized enterprises. Journal of Social Science Studies, 2, 259-274. http://dx.doi.org/10.5296/jsss.v2i2.7659

Low, M. P., \& Ong, S. F. (2015b). The role of internal corporate social responsibility in professional service sector: An empirical study from Klang Valley, Malaysia. Asia Pacific Journal of Advanced Business and Social Studies, 1(1).

Low, M. P., Ong, S. F., \& Tan, P. M. (2017). Would internal corporate social responsibility make a difference in professional service industry employees' turnover intention? A two-stage approach using PLS-SEM. Global Business and Management Research: An International Journal, 9(1), $24-41$

Luu, T. (2017). CSR and organizational citizenship behavior for the environment in hotel industry: The moderating role of corporate entrepreneurship and employee attachment style. International Journal of Contemporary Hospitality Management, 9(11), 2867-2900. https://doi.org/10.1108/IJCHM-02-2016-0080

Malik, M. S., Ali, H., \& Ishfaq, A. (2015). Corporate social responsibility and organizational performance: Empirical evidence from banking sector. Pakistan Journal of Commerce and Social Sciences, 9(1).

Newman, A., Nielsen, I., \& Miao, Q. (2015). The impact of employee perceptions of organizational corporate social responsibility practices on job performance and organizational citizenship behavior: Evidence from the Chines private sector. The International Journal of Human Resource Management, 26(9), 1-32. https://doi.org/10.1080/09585192.2014.934892

Obeidat, B. Y. (2016). Exploring the relationship between corporate social responsibility, employee engagement and organizational performance: The case of Jordanian mobile telecommunication companies. International Journal of Communications, Network and System Sciences, 9(9). http://doi.10.4236/ijens.2016.99032

O'Reilly, C. A., \& Chatman, J. (1986). Organizational commitment and psychological attachment: The effects of compliance, identification, and internalization on prosocial behaviour. Journal of applied psychology, 71(3), 492.

Rauf, F. H. A. (2015). What role does job satisfaction play on the relationship between organizational justice perception and organizational citizenship behavior? Empirical evidence from Sri Lankan employees. European Journal of Business and Management, 7, 149-162. https://www.iiste.org 
Sarfraz, M., Qun, W., Abdullah, M. I., \& Alvi, A. T. (2018). Employees' Perception of Corporate Social Responsibility Impact on Employee Outcomes: Mediating Role on Organizational Justice for Small and Medium Enterprises (SMEs). Sustainability, 10, 2429. https://doi.10.3390/su10072429

Shin, I., Hur, W.-M., \& Kang, S. (2016). Employees' perception of corporate social responsibility and job performance: A Sequential Mediation model. Sustainability Journal, 8(5). https://doi:10.3390/su8050493

Singh, S. K., Darwish, T., \& Potocnik, K. (2016). Measuring organizational performance: A case for subjective measures. British Journal of Management, 27, 214 -224. https://doi.10.1111/14678551.12126

Yaghoobi, T., \& Haddadi, F. (2016). Organizational performance measurement by a framework integrating BSC and AHP. International Journal of Productivity and Performance Management, 65(7), 959-976. https://doi.org/10.1108/IJPPM-01-2015-0001

Zafar, M., \& Ali, I. (2016). The influence of corporate social responsibility on employee commitment: The mediating role of employee company identification. Asian Social Science, 12(1). https://dx.doi.org/10.5539/ass.v12n12p262

Zahari, A. R., Elinda, E., Rajadurai, J., Azizan, N. A., \& Muhammad Tamyez, P. F. (2020). The effect of corporate social responsibility practices on brand equity: An examination of Malaysia's Top 100 Brands. Journal of Asian Finance, Economics and Business, 7(2), 271-280. https://doi:10.13106/jafeb.2020.vol7.no2 